\title{
Neurology"
}

\section{Late seizures in cerebral venous thrombosis}

Sánchez van Kammen M, MD ${ }^{1, *}$, Lindgren E, $\mathrm{MD}^{2,{ }^{*}}$, Silvis $\mathrm{SM}, \mathrm{MD}^{1}$, Hiltunen $\mathrm{S}, \mathrm{MD}, \mathrm{PhD}^{3}$, Heldner MR, MD, MSc ${ }^{4}$, Serrano F, MD ${ }^{5}$, Zelano J, MD, $\mathrm{PhD}^{2}$, Zuurbier SM, MD, $\mathrm{PhD}^{1}$, Mansour M, $\mathrm{MD}^{6}$, Aguiar de Sousa D, MD, MSc, $\mathrm{PhD}^{7}$, Canhão P, MD, $\mathrm{PhD}^{7}, \mathrm{Al}$-Asady S, $\mathrm{MD}^{8}$, Ekizoglu E, $\mathrm{MD}^{9}$, Redfors $\mathrm{P}, \mathrm{MD}, \mathrm{PhD}^{2}$, Yesilot N, MD ${ }^{9}$, Ghiasian M, MD, $\mathrm{PhD}^{6}$, Barboza MA, MD, $\mathrm{PhD}^{10}$, Arnao V, MD, $\mathrm{PhD}^{11}$, Aridon P, MD, $\mathrm{PhD}^{11}$, Punter MNM, MD, $\mathrm{PhD}^{8}$, Ferro JM, MD, $\mathrm{PhD}^{7}$, Arauz A, MD, $\mathrm{PhD}^{5}$, Tatlisumak T, MD, $\mathrm{PhD}^{2,3}$, Arnold M, $\mathrm{MD}^{4}$, Putaala J, MD, $\mathrm{PhD}^{3}$, Jood K, MD, $\mathrm{PhD}^{2, * *}$, Coutinho JM, MD, $\mathrm{PhD}^{1, * *}$

${ }^{*, * *}$ These authors contributed equally to the manuscript.

Neurology® Published Ahead of Print articles have been peer reviewed and accepted for publication. This manuscript will be published in its final form after copyediting, page composition, and review of proofs. Errors that could affect the content may be corrected during these processes. 
1. Department of Neurology, Amsterdam UMC, University of Amsterdam, Amsterdam, The Netherlands

2. Department of Clinical Neuroscience, Institute of Neuroscience and Physiology, Sahlgrenska Academy at University of Gothenburg and Department of Neurology, Sahlgrenska University Hospital, Gothenburg, Sweden

3. Department of Neurology, Helsinki University Hospital and University of Helsinki, Helsinki, Finland

4. Department of Neurology, Inselspital, Bern University Hospital and University of Bern, Bern, Switzerland

5. National Institute of Neurology and Neurosurgery Manuel Velasco Suarez, Mexico-City, Mexico

6. Sina Hospital, Hamadan University of Medical Science, Hamadan, Iran

7. Department of Neurosciences and Mental Health (Neurology), Hospital de Santa Maria/CHULN; University of Lisbon, Lisbon, Portugal

8. Manchester Centre for Clinical Neurosciences, Salford Royal NHS Foundation Trust, Manchester, United Kingdom

9. Department of Neurology, Istanbul Faculty of Medicine, Istanbul University, Istanbul, Turkey

10. Neurosciences Department, Hospital Dr. R.A. Calderón Guardia, CCSS, San José, Costa Rica

11. Department of Biomedicine, Neuroscience and Advanced Diagnostics (Bi.N.D), University of Palermo, Palermo, Italy 
Correspondence to: Turgut Tatlisumak, MD, $\mathrm{PhD}$, turgut.tatlisumak@neuro.gu.se

Word count: 2345

Word count in abstract: 250

Character count title: 43

Number of references: 27

Number of tables: 4

Number of figures: 2

Statistical analyses conducted by MSvK and EL.

Key words: cerebral venous thrombosis; seizures; epilepsy; prediction; outcome

\section{Study Funding}

E Lindgren has received academic grants from The Swedish Neurological Society, Elsa and Gustav Lindh's Foundation, P-o Ahl's Foundation and Rune and Ulla Amlöv's Foundation for research on CVT. J Zelano has received academic grants from the Swedish Society of Medical Research (SSMF) for research on acquired epilepsy. T Tatlisumak has received academic grants from Sahlgrenska University Hospital and University of Gothenburg for research on CVT. M Arnold has received a Swiss Heart Foundation Grant for this study.

\section{Disclosures}

M Sánchez van Kammen, E Lindgren, S Silvis, S Hiltunen, M Heldner, and F Serrano report no disclosures relevant to the manuscript. 
J Zelano reports a consultancy fee from the Swedish Medical Product Agency, speaker honoraria from UCB, and has as an employee of Sahlgrenska University Hospital been investigator/subinvestigator in clinical trials sponsored by GW Pharma, Bial, UCB, and SK life science (no personal compensation).

S Zuurbier, M Mansour, D Aguiar de Sousa, P Canhão, S Al-Asady, E Ekizoglu, P Redfors, N Yesilot, M Ghiasian, M Barboza, V Arnao, and P Aridon report no disclosures relevant to the manuscript.

M Punter has received honorarium from Alexion Pharmaceuticals and has been investigator in a clinical trial sponsored by Lundbeck.

J Ferro, A Arauz, T Tatlisumak, M Arnold, J Putaala, and K Jood report no disclosures relevant to the manuscript.

J Coutinho has received research funding for CVT research from Boehringer and Bayer. All fees were paid to J Coutinho's institute (no personal compensation). 


\begin{abstract}
Objective: To examine the incidence, characteristics, treatment, and predictors of late seizures (LS) after cerebral venous thrombosis (CVT), we described these features in a registry of 1,127 patients with CVT.
\end{abstract}

Methods: We included consecutive adult patients from an international consortium of twelve hospital-based CVT registries. We excluded patients with a history of epilepsy or with $<8$ days of follow-up. We defined LS as seizures occurring $>7$ days after diagnosis of CVT. We used multivariable Cox regression to identify predictors of LS.

Results: We included 1,127 patients with CVT. During a median follow-up of 2.0 years (interquartile range [IQR] 1.0-6.3), 123 patients (11\%) experienced one or more LS (incidence rate for first LS 30 per 1,000 person-years, 95\%CI 25-35). Median time to first LS was 5 months (IQR 1-16). Baseline predictors of LS included status epilepticus in the acute phase (Hazard Ratio [HR] 7.0, 95\%CI 3.9-12.6), acute seizure(s) without status epilepticus (HR 4.1, 95\%CI 2.5-6.5), intracerebral hemorrhage (HR 1.9, 95\%CI 1.1-3.1), subdural hematoma (HR 2.3, 95\%CI 1.1-4.9) and decompressive hemicraniectomy (HR 4.2, 95\%CI 2.4-7.3). Eighty-five patients (70\% of patients with LS) experienced a recurrent seizure during follow-up, despite the fact that $94 \%$ received anti-epileptic drug treatment after the first LS.

Conclusion: During a median follow-up of two years, approximately one in ten patients with CVT had LS. Patients with baseline intracranial bleeding, acute symptomatic seizures, and those who underwent decompressive hemicraniectomy were at increased risk of developing LS. The high recurrence risk of LS justifies epilepsy diagnosis after a first LS. 


\section{Introduction}

Seizures are an important complication in the acute phase of cerebral venous thrombosis (CVT), occurring in about $40 \%$ of patients. ${ }^{1-3}$ Recognized risk factors for acute symptomatic seizures include focal neurological deficits, supratentorial parenchymal lesions, intracerebral hemorrhage (ICH), focal edema/infarction, superior sagittal sinus thrombosis, cortical vein thrombosis, and pregnancy or puerperium. ${ }^{2,4-7}$ In contrast, much less is known about the frequency and risk factors for late seizures after CVT. In the International Study on Cerebral Vein and Dural Sinus Thrombosis (ISCVT), 11\% of patients had one or more late seizures during a median follow-up time of 16 months, but a detailed analysis of the incidence and recurrence rate, predictors, and characteristics of late seizures after CVT has not been performed. ${ }^{1}$ Only small, single center cohort studies have examined predictors of late seizures after CVT. Identified risk factors for late seizures included acute symptomatic seizures, ICH at baseline, sigmoid sinus thrombosis, loss of consciousness at presentation, and genetic thrombophilia. ${ }^{1,8}$ No studies have been performed on seizure characteristics, recurrence risk, and treatment of late seizures after CVT. Seizure recurrence risk is of special importance since it determines whether or not epilepsy should be diagnosed after a single late seizure. The International League Against Epilepsy (ILAE) recommends diagnosis of epilepsy after one unprovoked seizure in patients with $>60 \%$ risk of seizure recurrence within 10 years. ${ }^{9}$ Due to the lack of data, current guidelines do not provide recommendations regarding the prevention or treatment of late seizures after CVT. ${ }^{10,11}$ Here, we describe the incidence, characteristics, treatment, and predictors of late seizures in a large international multicenter cohort of consecutive adult patients with CVT. 


\section{Methods}

\section{$\underline{\text { Study design and patient selection }}$}

We used data from the international CVT consortium, which is an ongoing collaboration between CVT research groups from 12 hospitals. ${ }^{12-14}$ Details of the consortium are described in the side-by-side article on acute symptomatic seizures in CVT in this issue. ${ }^{15}$ We included consecutive adult patients who were diagnosed with CVT until December 2018 and who had a minimum of 8 days of follow-up. We excluded patients with pre-existing epilepsy at time of CVT diagnosis.

\section{$\underline{\text { Data collection and definitions }}$}

A detailed description of the baseline data collection and definitions used in this study can be found in the preceding article on acute symptomatic seizures in CVT. ${ }^{15}$ We defined late seizures as any seizure occurring more than seven days after the diagnosis of CVT, in accordance with the recommendations of the ILAE. ${ }^{16}$ For patients with late seizures, we collected additional data on anti-epileptic drug (AED) use at the time of first late seizure, treatment of first late seizure, if hospital or intensive care unit (ICU) admission was required due to late seizures, recurrence of late seizures, and dates of first and, if applicable, second late seizure.

\section{$\underline{\text { Standard Protocol Approvals, Registration, and Patient Consents }}$}

Each center received permission from local authorities and ethic committees to collect observational data, and obtained written informed consent, when this was required under applicable national laws. 


\section{Data Availability}

All study data are available upon reasonable request.

\section{$\underline{\text { Statistical analyses }}$}

We report non-normally distributed data as medians, interquartile ranges (IQRs), and occasionally with $10^{\text {th }}$ and $90^{\text {th }}$ percentiles (p10-p90). We used the Wilson procedure to calculate $95 \%$ CIs for binomial proportions. We compared patients with late seizures to those without late seizures using Fisher's exact test for dichotomous data, and the Mann-Whitney-U test for continuous data. We calculated the incidence rate of first late seizures per 1,000 person-years in our cohort. Late seizure-free survival rates are depicted with a Kaplan-Meier plot. Cases without late seizures during follow-up were censored at the time of the last followup assessment. In a sensitivity analysis, we compared late seizure-free survival rates among prospectively and retrospectively enrolled patients using the log-rank test. We assessed predictors of late seizures using univariable and multivariable Cox regression analysis. We selected potential predictors based on clinical plausibility, ease of clinical use, and univariate analysis (variables with a positive probability value below 0.1 were considered). The following potential predictors were selected: age, status epilepticus in the acute phase, acute symptomatic seizures without status epilepticus, focal neurologic deficits, $\mathrm{ICH}$, focal edema without parenchymal hemorrhage, sulcal subarachnoid hemorrhage, subdural hematoma, superior sagittal sinus thrombosis, and decompressive hemicraniectomy. Data were missing in $<1 \%$ of cases for all variables included in the Cox regression, and these cases were excluded from this specific analysis. The proportional hazards assumption was evaluated graphically based on Schoenfeld residuals and log minus log plots for each covariate. We calculated hazard ratios (HR) with $95 \%$ CIs. In a sensitivity analysis, we added prospective enrollment 
as a covariate to the Cox regression analysis and examined the effect on other predictors.

Lastly, we described the proportions of the potential predictors of late seizures among patients with late seizures who did and did not have recurrent late seizure(s)._We analyzed all data with IBM SPSS Statistics 23.0 (International Business Machines Corporation, New York). 


\section{Results}

There were 1,308 adult patients diagnosed with CVT within the study period. Patients from the Royal Adelaide Hospital ( $\mathrm{n}=99)$ were excluded due to lack of follow-up data. From the remaining 11 hospitals, another 82 patients were excluded, leaving 1,127 patients in the analysis (Figure 1). In total, 687 patients (61\%) were enrolled prospectively and $440(39 \%)$ were identified retrospectively.

During a median follow-up of 2.0 years (IQR 1.0-6.3, p10-p90 0.4-11.3), 123 (11\%) patients experienced one or more late seizures. The incidence rate of first late seizures was 30 per 1,000 person-years (95\% CI 25-35). Cumulative late seizure-free survival rates are depicted in Figure 2. Late seizures-free survival rates were similar among prospectively and retrospectively enrolled patients $(\mathrm{p}=0.24)$. Median time to first late seizure was five months (IQR 1-16, p10-p90 0-39), and 84 patients (68\% of patients with late seizures) had the first late seizure within one year after CVT diagnosis. Eighty-five patients (70\% of patients with late seizures, 95\% CI 61-77) had recurrent late seizures during a median follow-up of 2.6 years (IQR 0.6-6.1) after the first late seizure. Median time to seizure recurrence was one month (IQR 0-8).

Baseline information is presented in Table 1. Patients who developed late seizures more often had focal neurological deficits, coma, and acute symptomatic seizures on initial admission for CVT. On baseline imaging, ICH, sulcal subarachnoid hemorrhage, and subdural hematoma were more common among patients who developed late seizures. Patients with late seizures also more often had thrombosis of the superior sagittal sinus and cortical veins, had longer 
initial hospital admissions, and had more often undergone decompressive hemicraniectomy in the acute phase.

Late seizures occurred in 88/406 (22\%) of patients with acute symptomatic seizures, 26/77 $(34 \%)$ of patients with status epilepticus in the acute phase, $72 / 365(20 \%)$ of patients with baseline ICH, 8/29 (28\%) of patients with subdural hematoma, and 17/45 (38\%) of patients who underwent decompressive hemicraniectomy.

Characteristics and treatment of late seizures are presented in Table 2. Two patients (2\%) died during hospital admission due to late seizures. One patient died due to terminal renal failure and simultaneous posterior reversible encephalopathy syndrome, and one patient due to complications of limbic encephalitis. One patient $(<1 \%)$ had a late seizure due to recurrent CVT. After a first late seizure, the vast majority of patients were either started on, or continued, AED treatment (Table 2). The most commonly prescribed AEDs were levetiracetam, carbamazepine, and valproic acid. No patient underwent epilepsy surgery.

No major deviations from the assumption of proportional hazards were found by graphical interpretation of Schoenfeld residuals and log minus log plots. Results of the Cox regression analysis are shown in Table 3. Statistically significant predictors of late seizures were: status epilepticus in the acute phase, acute symptomatic seizures without status epilepticus, ICH, subdural hematoma, and decompressive hemicraniectomy. In the sensitivity analysis, adding prospective enrollment as a covariate to the regression analysis did not affect the results (HR 1.0, 95\%CI 0.7-1.5). We compared the potential predictors of late seizures among patients with late seizures who did and did not have recurrent late seizure(s) (Table 4). There were no 
major differences in the distribution of these predictors among both groups, although subdural hematoma at baseline was more frequently seen among patients with single versus recurrent late seizures. However, the total number of patients with both baseline subdural hematoma and late seizure(s) was only eight. 


\section{Discussion}

In this study, approximately one in ten patients with CVT had one or more late seizures during a median follow-up of two years. Seventy percent of patients who experienced a first late seizure had recurrent late seizure(s) within the study period, despite the fact that $94 \%$ received AED treatment after the first late seizure. Given this high recurrence risk, diagnosis of epilepsy is reasonable after a first late seizure after CVT in accordance with the current ILAE definition. ${ }^{9}$ Status epilepticus in the acute phase, acute symptomatic seizures without status epilepticus, ICH, subdural hematoma, and decompressive hemicraniectomy were predictors of late seizures.

Our findings are in accordance with the frequency of late seizures reported in the ISCVT ${ }^{1}$ and in between the estimated incidence of late seizures after ischemic stroke and intracerebral hemorrhage (18 and 40 per 1,000 person-years, respectively). ${ }^{17,18}$ Our estimate is somewhat higher than that of a retrospective cohort study among 537 young stroke patients (18-50 years; ischemic stroke, ICH, or transient ischemic attack). In this study, $42(8 \%)$ patients had late seizures during a mean follow-up of 9.8 years (SD 8.4). ${ }^{19}$

The incidence of late seizures in CVT is considerable in light of the clinical experience that the impact of late seizures can be devastating on the physical and mental wellbeing of CVT patients. A large proportion of patients experience recurrent late seizures, and fear of new seizures negatively influences quality of life..$^{20}$ Moreover, both patients and physicians often fear recurrence of CVT when a patient has a late seizure. The results of our study do not seem to justify that fear, since late seizures coincided with recurrent CVT in less than $1 \%$ of the cases. The high proportion of patients with hospitalizations due to late seizures and status epilepticus further underlines the impact of late seizures after CVT. 
Guidelines suggest to start AED therapy after a single late seizure in stroke patients because of the high risk of seizure recurrence. ${ }^{21}$ Our study is the first to confirm this high recurrence risk in the subgroup of CVT patients, which would justify a similar treatment approach. This practice is reflected in our cohort: $94 \%$ of patients were on AEDs directly after the first late seizure. The high rate of late seizure recurrence despite AED therapy suggests that this patient group may be in need of more optimized treatment strategies. The most commonly used AEDs in our cohort were levetiracetam, carbamazepine, and valproic acid. When prescribing AEDs for late seizures after CVT, clinicians should keep in mind that 1) enzyme-inducing AEDs and valproic acid interact with oral anticoagulants, ${ }^{22,23}$ 2) valproic acid should be avoided in women of childbearing age, ${ }^{24}$ which encompasses a substantial proportion of patients with $\mathrm{CVT},{ }^{25}$ and 3) AED withdrawal may be attempted in patients who have remained seizure-free for a prolonged period of time, as epilepsy is not necessarily a diagnosis for life and may resolve over time. ${ }^{9}$

Predictors of late seizures in our cohort were status epilepticus in the acute phase, acute symptomatic seizures without status epilepticus, ICH (including hemorrhagic infarcts), subdural hematoma, and decompressive hemicraniectomy. These predictors were more or less equally distributed at baseline among patients with single and multiple late seizures during follow-up. ICH and acute symptomatic seizures have also been associated with late seizures after CVT in small cohort studies. ${ }^{5,8}$ Predictors of late seizures in other stroke types include ICH, stroke severity and cortical involvement. ${ }^{26}$ Although no causal inferences can be made based on these studies, these results seem to be in line with the hypothesis that late seizures arise from structural lesions leading to permanent changes in neuro-excitability. ${ }^{27}$ Interestingly, for CVT patients with focal edema without parenchymal hemorrhage, the risk of late seizures was not increased, despite this being a predictor of acute symptomatic seizures. ${ }^{2,5,6}$ A possible explanation might be that the radiological finding of non-hemorrhagic 
lesions at least to some extent represents reversible damage such as vasogenic edema, entailing increased risk of seizures in the acute phase which declines over time. The association between decompressive hemicraniectomy in the acute phase and the occurrence of late seizures is most likely explained by the extensive parenchymal lesions that these patients often have, but might also be influenced by the surgical procedure itself. Regardless of whether a causal relation between decompressive surgery and late seizures exists, it is important for physicians to be aware of the fact that about $1 / 3$ patients with CVT who undergo this procedure in the acute phase develop late seizures. Similarly, $1 / 3$ patients with CVT and status epilepticus in the acute phase develop late seizures.

Several limitations of our study warrant comment. First, data for this study were in part collected retrospectively. Second, estimations of risk and risk factors for late seizures are likely affected by variations in AED use between patients. Thus, this study describes observed risks and predictors in 'real world data' rather than describing the natural course after CVT without any AED treatment. Third, because most centers in the CVT consortium function as a tertiary referral center for CVT, the current cohort may have an overrepresentation of severe cases, and thus of late seizures. Finally, due to the observational design of the study, we were not able to assess treatment effects of AEDs. The assessment of AED treatment efficacy would, among other potential confounding factors, require taking into account exact dosages, AED serum concentrations, treatment duration, and might justify a separate study to be answered properly.

In summary, during a median follow-up time of two years, about one in ten CVT patients had one or more late seizures. Status epilepticus in the acute phase, acute symptomatic seizures without status epilepticus, ICH, subdural hematoma, and decompressive hemicraniectomy were predictors of late seizures. The high recurrence risk of late seizures justifies a diagnosis of epilepsy after a first late seizure. 


\section{Acknowledgments}

The authors thank Judith Klecki for assisting with English language editing.

\section{Appendix 1: Authors}

\begin{tabular}{|c|c|c|}
\hline Name & Location & Contributions \\
\hline $\begin{array}{l}\text { Mayte Sánchez van } \\
\text { Kammen, MD }\end{array}$ & $\begin{array}{l}\text { Department of Neurology, } \\
\text { Amsterdam UMC, University of } \\
\text { Amsterdam, The Netherlands }\end{array}$ & $\begin{array}{l}\text { Designed and conceptualized } \\
\text { the study; analyzed the data; } \\
\text { major role in the acquisition of } \\
\text { data; drafted the manuscript for } \\
\text { intellectual content }\end{array}$ \\
\hline Erik Lindgren, MD & $\begin{array}{l}\text { Department of Clinical } \\
\text { Neuroscience, Institute of } \\
\text { Neuroscience and Physiology, } \\
\text { Sahlgrenska Academy at University } \\
\text { of Gothenburg and Department of } \\
\text { Neurology, Sahlgrenska University } \\
\text { Hospital, Gothenburg, Sweden }\end{array}$ & $\begin{array}{l}\text { Designed and conceptualized } \\
\text { the study; analyzed the data; } \\
\text { major role in the acquisition of } \\
\text { data; drafted the manuscript for } \\
\text { intellectual content }\end{array}$ \\
\hline $\begin{array}{l}\text { Suzanne M Silvis, } \\
\text { MD }\end{array}$ & $\begin{array}{l}\text { Department of Neurology, } \\
\text { Amsterdam UMC, University of } \\
\text { Amsterdam, The Netherlands }\end{array}$ & $\begin{array}{l}\text { Designed and conceptualized } \\
\text { the study; analyzed the data; } \\
\text { major role in the acquisition of } \\
\text { data; drafted the manuscript for } \\
\text { intellectual content }\end{array}$ \\
\hline
\end{tabular}




\begin{tabular}{|c|c|c|}
\hline $\begin{array}{l}\text { Sini Hiltunen, MD, } \\
\mathrm{PhD}\end{array}$ & $\begin{array}{l}\text { Department of Neurology, Helsinki } \\
\text { University Hospital and University } \\
\text { of Helsinki, Helsinki, Finland }\end{array}$ & $\begin{array}{l}\text { Major role in the acquisition of } \\
\text { data; revised the manuscript for } \\
\text { intellectual content }\end{array}$ \\
\hline $\begin{array}{l}\text { Mirjam R Heldner, } \\
\text { MD, MSc }\end{array}$ & $\begin{array}{l}\text { Department of Neurology, } \\
\text { Inselspital, Bern University } \\
\text { Hospital and University of Bern, } \\
\text { Bern, Switzerland }\end{array}$ & $\begin{array}{l}\text { Major role in the acquisition of } \\
\text { data; revised the manuscript for } \\
\text { intellectual content }\end{array}$ \\
\hline $\begin{array}{l}\text { Fabiola Serrano, } \\
\text { MD }\end{array}$ & $\begin{array}{l}\text { National Institute of Neurology and } \\
\text { Neurosurgery Manuel Velasco } \\
\text { Suarez, Mexico-City, Mexico }\end{array}$ & $\begin{array}{l}\text { Major role in the acquisition of } \\
\text { data; revised the manuscript for } \\
\text { intellectual content }\end{array}$ \\
\hline $\begin{array}{l}\text { Johan Zelano, MD, } \\
\text { PhD }\end{array}$ & $\begin{array}{l}\text { Department of Clinical } \\
\text { Neuroscience, Institute of } \\
\text { Neuroscience and Physiology, } \\
\text { Sahlgrenska Academy at University } \\
\text { of Gothenburg and Department of } \\
\text { Neurology, Sahlgrenska University } \\
\text { Hospital, Gothenburg, Sweden }\end{array}$ & $\begin{array}{l}\text { Designed and conceptualized } \\
\text { the study; interpreted the data; } \\
\text { revised the manuscript for } \\
\text { intellectual content }\end{array}$ \\
\hline $\begin{array}{l}\text { Susanna M. } \\
\text { Zuurbier, MD, Phl }\end{array}$ & $\begin{array}{l}\text { Amsterdam University Medical } \\
\text { Center, Amsterdam, The } \\
\text { Netherlands }\end{array}$ & $\begin{array}{l}\text { Major role in the acquisition of } \\
\text { data; revised the manuscript for } \\
\text { intellectual content }\end{array}$ \\
\hline $\begin{array}{l}\text { Maryam Mansour, } \\
\text { MD }\end{array}$ & $\begin{array}{l}\text { Sina Hospital, Hamadan University } \\
\text { of Medical Science, Hamadan, Iran }\end{array}$ & $\begin{array}{l}\text { Major role in the acquisition of } \\
\text { data; revised the manuscript for } \\
\text { intellectual content }\end{array}$ \\
\hline $\begin{array}{l}\text { Diana Aguiar de } \\
\text { Sousa, MD, MSc, }\end{array}$ & $\begin{array}{l}\text { Department of Neurosciences and } \\
\text { Mental Health, Hospital de Santa }\end{array}$ & $\begin{array}{l}\text { Major role in the acquisition of } \\
\text { data; revised the manuscript for }\end{array}$ \\
\hline
\end{tabular}




\begin{tabular}{|c|c|c|}
\hline $\mathrm{PhD}$ & $\begin{array}{l}\text { Maria/CHULN; University of } \\
\text { Lisbon, Lisbon, Portugal }\end{array}$ & intellectual content \\
\hline $\begin{array}{l}\text { Patrícia Canhão, } \\
\text { MD }\end{array}$ & $\begin{array}{l}\text { Department of Neurosciences and } \\
\text { Mental Health, Hospital de Santa } \\
\text { Maria/CHULN; University of } \\
\text { Lisbon, Lisbon, Portugal }\end{array}$ & $\begin{array}{l}\text { Major role in the acquisition of } \\
\text { data; revised the manuscript for } \\
\text { intellectual content }\end{array}$ \\
\hline Saleem Al-Asady & $\begin{array}{l}\text { Faculty of Biology, Medicine and } \\
\text { Health, Manchester Medical } \\
\text { School, University of Manchester, } \\
\text { Manchester, United Kingdom }\end{array}$ & $\begin{array}{l}\text { Major role in the acquisition of } \\
\text { data; revised the manuscript for } \\
\text { intellectual content }\end{array}$ \\
\hline $\begin{array}{l}\text { Esme Ekizoglu, } \\
\text { MD }\end{array}$ & $\begin{array}{l}\text { Department of Neurology, Ista } \\
\text { Faculty of Medicine, Istanbul } \\
\text { University, Istanbul, Turkey }\end{array}$ & $\begin{array}{l}\text { Major role in the acquisition of } \\
\text { data; revised the manuscript for } \\
\text { intellectual content }\end{array}$ \\
\hline $\begin{array}{l}\text { Petra Redfors, MD, } \\
\mathrm{PhD}\end{array}$ & $\begin{array}{l}\text { Department of Clinical } \\
\text { Neuroscience, Institute of } \\
\text { Neuroscience and Physiology, } \\
\text { Sahlgrenska Academy at University } \\
\text { of Gothenburg and Department of } \\
\text { Neurology, Sahlgrenska University } \\
\text { Hospital, Gothenburg, Sweden }\end{array}$ & $\begin{array}{l}\text { Designed and conceptualized } \\
\text { the study; interpreted the data; } \\
\text { revised the manuscript for } \\
\text { intellectual content }\end{array}$ \\
\hline $\begin{array}{l}\text { Nilufer Yesilot, } \\
\text { MD }\end{array}$ & $\begin{array}{l}\text { Department of Neurology, Istanbul } \\
\text { Faculty of Medicine, Istanbul } \\
\text { University, Istanbul, Turkey }\end{array}$ & $\begin{array}{l}\text { Major role in the acquisition of } \\
\text { data; revised the manuscript for } \\
\text { intellectual content }\end{array}$ \\
\hline $\begin{array}{l}\text { Masoud Ghiasian, } \\
\mathrm{MD}, \mathrm{PhD}\end{array}$ & $\begin{array}{l}\text { Sina Hospital, Hamadan University } \\
\text { of Medical Science, Hamadan, Iran }\end{array}$ & $\begin{array}{l}\text { Major role in the acquisition of } \\
\text { data; revised the manuscript for }\end{array}$ \\
\hline
\end{tabular}




\begin{tabular}{|c|c|c|}
\hline & & intellectual content \\
\hline $\begin{array}{l}\text { Miguel A Barboza, } \\
\mathrm{MD}, \mathrm{PhD}\end{array}$ & $\begin{array}{l}\text { Neurosciences Department, } \\
\text { Hospital Dr. R.A. Calderón } \\
\text { Guardia, CCSS, San José, Costa } \\
\text { Rica }\end{array}$ & $\begin{array}{l}\text { Major role in the acquisition of } \\
\text { data; revised the manuscript for } \\
\text { intellectual content }\end{array}$ \\
\hline $\begin{array}{l}\text { Valencia Arnao, } \\
\mathrm{MD}, \mathrm{PhD}\end{array}$ & $\begin{array}{l}\text { Department of Biomedicine, } \\
\text { Neuroscience and Advanced } \\
\text { Diagnostics (Bi.N.D), University of } \\
\text { Palermo, Palermo, Italy }\end{array}$ & $\begin{array}{l}\text { Major role in the acquisition of } \\
\text { data; revised the manuscript for } \\
\text { intellectual content }\end{array}$ \\
\hline $\begin{array}{l}\text { Paolo Aridon, MD, } \\
\mathrm{PhD}\end{array}$ & $\begin{array}{l}\text { Department of Biomedicine, } \\
\text { Neuroscience and Advanced } \\
\text { Diagnostics (Bi.N.D), Univers } \\
\text { Palermo, Palermo, Italy }\end{array}$ & $\begin{array}{l}\text { Interpreted the data; revised the } \\
\text { manuscript for intellectual } \\
\text { content }\end{array}$ \\
\hline $\begin{array}{l}\text { Martin NM Punter, } \\
\mathrm{MD}, \mathrm{PhD}\end{array}$ & $\begin{array}{l}\text { Department of Neurology, Salford } \\
\text { Royal NHS Foundation Trust, } \\
\text { Manchester, United Kingdom }\end{array}$ & $\begin{array}{l}\text { Major role in the acquisition of } \\
\text { data; revised the manuscript for } \\
\text { intellectual content }\end{array}$ \\
\hline $\begin{array}{l}\text { José M Ferro, MD, } \\
\mathrm{PhD}\end{array}$ & $\begin{array}{l}\text { Department of Neurosciences and } \\
\text { Mental Health, Hospital de Santa } \\
\text { Maria/CHULN; University of } \\
\text { Lisbon, Lisbon, Portugal }\end{array}$ & $\begin{array}{l}\text { Major role in the acquisition of } \\
\text { data; Interpreted the data; } \\
\text { revised the manuscript for } \\
\text { intellectual content }\end{array}$ \\
\hline $\begin{array}{l}\text { Antonio Arauz, } \\
\mathrm{MD}, \mathrm{PhD}\end{array}$ & $\begin{array}{l}\text { National Institute of Neurology and } \\
\text { Neurosurgery Manuel Velasco } \\
\text { Suarez, Mexico-City, Mexico }\end{array}$ & $\begin{array}{l}\text { Major role in the acquisition of } \\
\text { data; Interpreted the data; } \\
\text { revised the manuscript for } \\
\text { intellectual content }\end{array}$ \\
\hline Turgut Tatlisumak, & Department of Clinical & Guarantor of the study; \\
\hline
\end{tabular}




\begin{tabular}{|c|c|c|}
\hline $\mathrm{MD}, \mathrm{PhD}$ & $\begin{array}{l}\text { Neuroscience, Institute of } \\
\text { Neuroscience and Physiology, } \\
\text { Sahlgrenska Academy at University } \\
\text { of Gothenburg and Department of } \\
\text { Neurology, Sahlgrenska University } \\
\text { Hospital, Gothenburg, Sweden. } \\
\text { Department of Neurology, Helsinki } \\
\text { University Hospital and University } \\
\text { of Helsinki, Helsinki, Finland }\end{array}$ & $\begin{array}{l}\text { designed and conceptualized } \\
\text { the study; major role in the } \\
\text { acquisition of data; interpreted } \\
\text { the data; revised the } \\
\text { manuscript for intellectual } \\
\text { content }\end{array}$ \\
\hline $\begin{array}{l}\text { Marcel Arnold, } \\
\text { MD, } \mathrm{PhD}\end{array}$ & $\begin{array}{l}\text { Department of Neurology, } \\
\text { Inselspital, Bern University } \\
\text { Hospital and University of } \\
\text { Bern, Switzerland }\end{array}$ & $\begin{array}{l}\text { Interpreted the data; revised the } \\
\text { manuscript for intellectual } \\
\text { content }\end{array}$ \\
\hline $\begin{array}{l}\text { Jukka Putaala, MD, } \\
\text { PhD }\end{array}$ & $\begin{array}{l}\text { Department of Neurology, Helsinki } \\
\text { University Hospital and University } \\
\text { of Helsinki, Helsinki, Finland }\end{array}$ & $\begin{array}{l}\text { Interpreted the data; major role } \\
\text { in the acquisition of data; } \\
\text { revised the manuscript for } \\
\text { intellectual content }\end{array}$ \\
\hline $\begin{array}{l}\text { Katarina Jood } \\
\mathrm{MD}, \mathrm{PhD}\end{array}$ & $\begin{array}{l}\text { Department of Clinical } \\
\text { Neuroscience, Institute of } \\
\text { Neuroscience and Physiology, } \\
\text { Sahlgrenska Academy at University } \\
\text { of Gothenburg and Department of } \\
\text { Neurology, Sahlgrenska University } \\
\text { Hospital, Gothenburg, Sweden }\end{array}$ & $\begin{array}{l}\text { Designed and conceptualized } \\
\text { the study; major role in the } \\
\text { acquisition of data; interpreted } \\
\text { the data; revised the } \\
\text { manuscript for intellectual } \\
\text { content }\end{array}$ \\
\hline Jonathan M & Department of Neurology, & Designed and conceptualized \\
\hline
\end{tabular}


Sánchez van Kammen M, Lindgren E, et al. Page 21 of 29

\begin{tabular}{|l|l|l|}
\hline Coutinho, MD, & Amsterdam UMC, University of & the study; major role in the \\
PhD & Amsterdam, The Netherlands & $\begin{array}{l}\text { acquisition of data; interpreted } \\
\text { the data; revised the } \\
\text { manuscript for intellectual } \\
\text { content }\end{array}$ \\
\end{tabular}




\section{References}

1. Ferro JM, Canhao P, Stam J, Bousser MG, Barinagarrementeria F, Investigators I. Prognosis of cerebral vein and dural sinus thrombosis: results of the International Study on Cerebral Vein and Dural Sinus Thrombosis (ISCVT). Stroke. 2004;35(3):664-670.

2. Masuhr F, Busch M, Amberger N, et al. Risk and predictors of early epileptic seizures in acute cerebral venous and sinus thrombosis. European journal of neurology. 2006;13(8):852-856.

3. Duman T, Uluduz D, Midi I, et al. A Multicenter Study of 1144 Patients with Cerebral Venous Thrombosis: The VENOST Study. J Stroke Cerebrovasc Dis. 2017;26(8):1848-1857.

4. Ferro JM, Canhao P, Bousser MG, Stam J, Barinagarrementeria F. Early seizures in cerebral vein and dural sinus thrombosis: risk factors and role of antiepileptics. Stroke. 2008;39(4):1152-1158.

5. Ferro JM, Correia M, Rosas MJ, Pinto AN, Neves G. Seizures in cerebral vein and dural sinus thrombosis. Cerebrovasc Dis. 2003;15(1-2):78-83.

6. Mahale R, Mehta A, John AA, et al. Acute seizures in cerebral venous sinus thrombosis: What predicts it? Epilepsy research. 2016;123:1-5.

7. Li H, Cui L, Chen Z, Chen Y. Risk factors for early-onset seizures in patients with cerebral venous sinus thrombosis: A meta-analysis of observational studies. Seizure. 2019;72:33-39.

8. Davoudi V, Keyhanian K, Saadatnia M. Risk factors for remote seizure development in patients with cerebral vein and dural sinus thrombosis. Seizure. 2014;23(2):135-139.

9. Fisher RS, Acevedo C, Arzimanoglou A, et al. ILAE official report: a practical clinical definition of epilepsy. Epilepsia. 2014;55(4):475-482.

10. Ferro JM, Bousser MG, Canhao P, et al. European Stroke Organisation guideline for the diagnosis and treatment of cerebral venous thrombosis - endorsed by the European Academy of Neurology. European journal of neurology. 2017;24(10):1203-1213.

11. Saposnik G, Barinagarrementeria F, Brown RD, Jr., et al. Diagnosis and management of cerebral venous thrombosis: a statement for healthcare professionals from the American Heart Association/American Stroke Association. Stroke. 2011;42(4):1158-1192.

12. Zuurbier SM, Hiltunen S, Lindgren E, et al. Cerebral Venous Thrombosis in Older Patients. Stroke. 2018;49(1):197-200.

13. Silvis SM, Lindgren E, Hiltunen S, et al. Postpartum Period Is a Risk Factor for Cerebral Venous Thrombosis. Stroke. 2019;50(2):501-503.

14. Silvis SM, Hiltunen $\mathrm{S}$, Lindgren $\mathrm{E}$, et al. Cancer and risk of cerebral venous thrombosis: a casecontrol study. Journal of thrombosis and haemostasis : JTH. 2018;16(1):90-95.

15. Lindgren $\mathrm{E}$, Silvis $\mathrm{SM}$, Hiltunen $\mathrm{S}$, et al. Acute symptomatic seizures in cerebral venous thrombosis. Neurology. 2020;xx(xx):xx.

16. Thurman DJ, Beghi E, Begley CE, et al. Standards for epidemiologic studies and surveillance of epilepsy. Epilepsia. 2011;52 Suppl 7:2-26.

17. Wang JZ, Vyas MV, Saposnik G, Burneo JG. Incidence and management of seizures after ischemic stroke: Systematic review and meta-analysis. Neurology. 2017;89(12):1220-1228.

18. Rossi C, De Herdt V, Dequatre-Ponchelle N, Henon H, Leys D, Cordonnier C. Incidence and predictors of late seizures in intracerebral hemorrhages. Stroke. 2013;44(6):1723-1725.

19. Arntz RM, Maaijwee NA, Rutten-Jacobs LC, et al. Epilepsy after TIA or stroke in young patients impairs long-term functional outcome: the FUTURE Study. Neurology. 2013;81(22):1907-1913.

20. Bishop M, Allen CA. The impact of epilepsy on quality of life: a qualitative analysis. Epilepsy \& Behavior. 2003;4(3):226-233.

21. Krumholz A, Shinnar S, French J, Gronseth G, Wiebe S. Evidence-based guideline: Management of an unprovoked first seizure in adults: Report of the Guideline Development 
Subcommittee of the American Academy of Neurology and the American Epilepsy Society. Neurology. 2015;85(17):1526-1527.

22. Perucca E. Clinically relevant drug interactions with antiepileptic drugs. Br J Clin Pharmacol. 2006;61(3):246-255.

23. Stollberger $\mathrm{C}$, Finsterer J. Interactions between non-vitamin $\mathrm{K}$ oral anticoagulants and antiepileptic drugs. Epilepsy research. 2016;126:98-101.

24. Jentink J, Loane MA, Dolk H, et al. Valproic Acid Monotherapy in Pregnancy and Major Congenital Malformations. New England Journal of Medicine. 2010;362(23):2185-2193.

25. Coutinho JM, Ferro JM, Canhao $P$, et al. Cerebral venous and sinus thrombosis in women. Stroke. 2009;40(7):2356-2361.

26. Zhang $C$, Wang $X$, Wang $Y$, et al. Risk factors for post-stroke seizures: a systematic review and meta-analysis. Epilepsy Res. 2014;108(10):1806-1816.

27. Bladin CF, Alexandrov AV, Bellavance A, et al. Seizures after stroke: a prospective multicenter study. Arch Neurol. 2000;57(11):1617-1622. 
Figure 1: Flowchart of patient selection

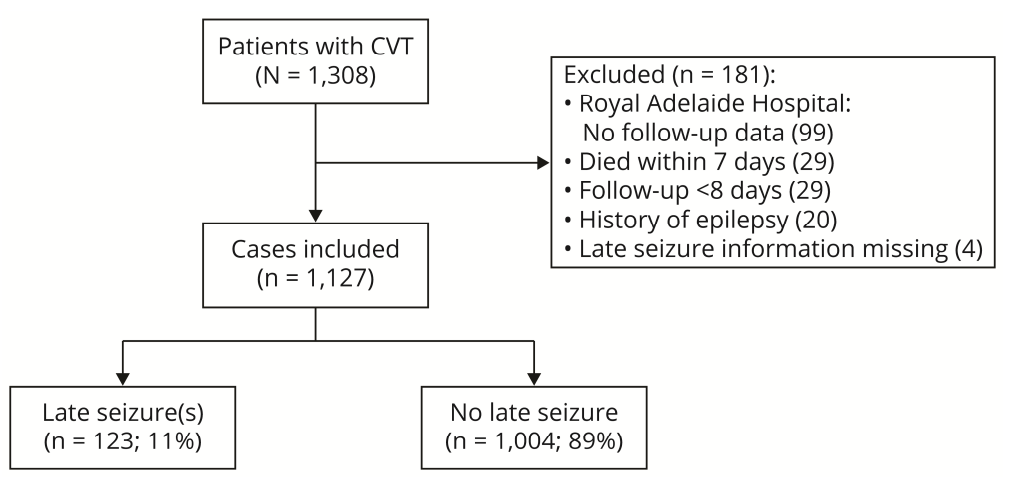

Figure 2: Cumulative late seizure-free survival after cerebral venous thrombosis

Abbreviations: $C V T=$ cerebral venous thrombosis; $C I=$ confidence interval

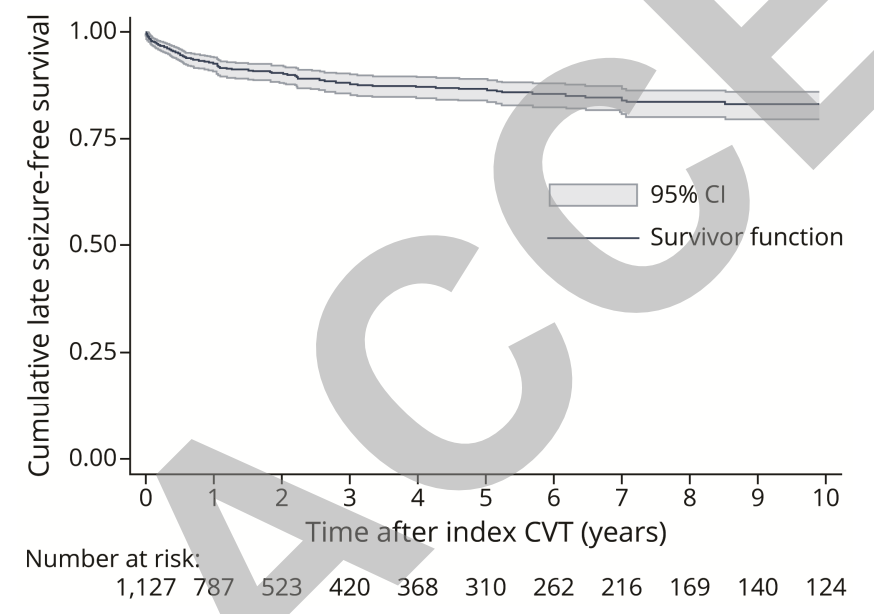


Table 1: Baseline data

\begin{tabular}{|c|c|c|c|}
\hline & Late seizure(s) & No late seizure & P-value \\
\hline & $\mathrm{n}=123$ & $\mathrm{n}=1,004$ & \\
\hline \multicolumn{4}{|l|}{ Demographics: } \\
\hline Women - n/N (\%) & $82 / 123(67 \%)$ & $709 / 1,004(71 \%)$ & 0.403 \\
\hline Age in years - median (IQR) ${ }^{\mathrm{a}}$ & $42(30-54)$ & $39(29-51)$ & 0.155 \\
\hline \multicolumn{4}{|l|}{$\begin{array}{l}\text { Clinical characteristics at baseline: } n / N \\
(\%)\end{array}$} \\
\hline Focal neurological deficits & 93/121 (77\%) & $555 / 1,001(55 \%)$ & $<0.001$ \\
\hline Coma $(\mathrm{GCS}<9)$ & $13 / 123(11 \%)$ & $38 / 997(4 \%)$ & 0.002 \\
\hline Acute symptomatic seizure & $88 / 123(72 \%)$ & $318 / 1,004(32 \%)$ & $<0.001$ \\
\hline Multiple acute symptomatic seizures & $60 / 120(50 \%)$ & $187 / 994(19 \%)$ & $<0.001$ \\
\hline Focal acute symptomatic seizures & $47 / 121(39 \%)$ & $131 / 1,001(13 \%)$ & $<0.001$ \\
\hline $\begin{array}{l}\text { Bilateral tonic-clonic acute } \\
\text { symptomatic seizures }\end{array}$ & $58 / 120(48 \%)$ & $236 / 1,002(24 \%)$ & $<0.001$ \\
\hline Status epilepticus & $26 / 121(22 \%)$ & $51 / 1,000(5 \%)$ & $<0.001$ \\
\hline $\begin{array}{l}\text { Acute symptomatic seizures without } \\
\text { status epilepticus }\end{array}$ & $62 / 121(51 \%)$ & $263 / 1,000(26 \%)$ & $<0.001$ \\
\hline \multicolumn{4}{|l|}{ Risk factors: $\mathbf{n} / \mathbf{N}(\%)$} \\
\hline Oral contraceptive use $\mathrm{e}^{\mathrm{b}}$ & $33 / 82(40 \%)$ & $303 / 703(43 \%)$ & 0.639 \\
\hline Hormone replacement therapy ${ }^{b}$ & $2 / 82(2 \%)$ & $34 / 708(5 \%)$ & 0.572 \\
\hline Pregnancy and puerperium $^{b}$ & $15 / 82(18 \%)$ & $86 / 709(12 \%)$ & 0.117 \\
\hline Eclampsia or pre-eclampsiab $^{\mathrm{b}}$ & $1 / 81(1 \%)$ & $3 / 708(0.4 \%)$ & 0.355 \\
\hline Any female-specific risk factor ${ }^{b}$ & $51 / 82(62 \%)$ & $424 / 707(60 \%)$ & 0.722 \\
\hline Cancer & $9 / 123(7 \%)$ & $89 / 1,001(9 \%)$ & 0.734 \\
\hline Infection & $19 / 123(15 \%)$ & $112 / 1,000(11 \%)$ & 0.180 \\
\hline Hereditary thrombophilia & $20 / 112(18 \%)$ & $163 / 895(18 \%)$ & 1.000 \\
\hline
\end{tabular}




\begin{tabular}{|c|c|c|c|}
\hline Imaging characteristics: $\mathbf{n} / \mathbf{N}(\%)$ & & & \\
\hline Intracerebral hemorrhage & $72 / 123(59 \%)$ & $293 / 1,004(29 \%)$ & $<0.001$ \\
\hline Cerebral edema/infarct only & $24 / 123(20 \%)$ & $186 / 1,004(19 \%)$ & 0.806 \\
\hline Sulcal subarachnoid hemorrhage & $18 / 123(15 \%)$ & $91 / 1,003(9 \%)$ & 0.053 \\
\hline Subdural hematoma & $8 / 122(7 \%)$ & $21 / 1,003(2 \%)$ & 0.009 \\
\hline Superior sagittal sinus thrombosis & $74 / 123(60 \%)$ & $503 / 1,001(50 \%)$ & 0.044 \\
\hline Lateral sinus thrombosis & $82 / 123(67 \%)$ & $695 / 1,002(69 \%)$ & 0.537 \\
\hline Cortical vein thrombosis & $34 / 123(28 \%)$ & $184 / 1,003(18 \%)$ & 0.021 \\
\hline Straight sinus thrombosis & $18 / 123(15 \%)$ & $(16 \%)$ & 0.794 \\
\hline \multicolumn{4}{|l|}{ Treatment and admission: $\mathrm{n} / \mathrm{N}(\%)$} \\
\hline Hospital stay in days - median $(\mathrm{IQR})^{\mathrm{c}}$ & $18(10-26)$ & $10(7-15)$ & $<0.001$ \\
\hline Intensive Care Unit admission & $43 / 123(35 \%)$ & $153 / 993(15 \%)$ & $<0.001$ \\
\hline Anticoagulation & $115 / 123(94 \%)$ & $960 / 1,001(96 \%)$ & 0.238 \\
\hline Decompressive hemicraniectomy & $17 / 123(14 \%)$ & $28 / 1,002(3 \%)$ & $<0.001$ \\
\hline
\end{tabular}

Abbreviations: $I Q R=$ interquartile range; $G C S=$ Glasgow Coma Scale;

${ }^{a}$ No missing data; ${ }^{b}$ percentage of women; ${ }^{c} 5 \%$ missing data 
Table 2: Characteristics and treatment of late seizures

\section{Patients with late seizure(s)}

$(\mathbf{n}=\mathbf{1 2 3})$

\section{Late seizure characteristics, $\mathrm{n} / \mathrm{N}(\%)$}

Focal

Bilateral tonic-clonic

Status epilepticus
$58 / 94(62 \%)$

$56 / 94(60 \%)$

$18 / 102(18 \%)$

Late seizure: acute treatment, $\mathbf{n} / \mathbf{N}$ (\%)

Benzodiazepines

Intravenous AED

Sedation

Hospital admission due to late seizures

ICU admission due to late seizures

Late seizure: prophylactic $\mathrm{AED}, \mathrm{n} / \mathrm{N}$

(\%)

AED treatment at time of first late seizures

AED started or continued after first late seizures

Levetiracetam

Carbamazepine

Valproic acid

Oxcarbazepine

Phenytoin

Other

Combination of AED
38/86 (44\%)

$31 / 87(36 \%)$

$14 / 88(16 \%)$

$76 / 122(62 \%)$

21/117 (18\%)

$30 / 66(46 \%)$

88/94 (94\%)

$27 / 94(29 \%)$

$19 / 94(20 \%)$

19/94 (19\%)

$8 / 94(9 \%)$

$3 / 94(3 \%)$

$3 / 94(3 \%)$

$10 / 94(11 \%)$

Abbreviations: $A E D=$ antiepileptic drug 
Table 3: Predictors of late seizures

\section{Univariable HR Multivariable} (95\% CI) HR (95\% CI)

\section{Baseline predictors}

Age (per decade increase)

$1.1(1.0-1.3) \quad 1.1(1.0-1.2)^{\mathrm{a}}$

Status epilepticus in the acute phase

$4.2(2.7-6.5) \quad 7.0(3.9-12.6)$

Acute symptomatic seizure (excluding status epilepticus)

$2.9(2.0-4.2) \quad 4.1(2.5-6.5)$

Focal neurologic deficits $2.6(1.7-4.0) \quad 1.2(0.7-1.9)$

Intracerebral hemorrhage $3.5(2.5-5.1) \quad 1.9(1.1-3.1)$

Cerebral edema/infarct only $0.9(0.6-1.4) \quad 1.2(0.6-2.1)$

Sulcal subarachnoid hemorrhage $1.8(1.1-3.0) \quad 1.0(0.6-1.8)$

Subdural hematoma

$2.8(1.4-5.7)$

$2.3(1.1-4.9)$

Superior sagittal sinus thrombosis

$1.4(1.0-2.0)$

$1.1(0.8-1.7)$

Decompressive hemicraniectomy

$5.6(3.3-9.3)$

$4.2(2.4-7.3)$

Abbreviations: $H R=$ hazard ratio $; C I=$ confidence interval ${ }^{a} p=0.18$ 
Table 4: Proportions of potential predictors of late seizures among patients with single and recurrent late seizures

\begin{tabular}{|c|c|c|}
\hline & \begin{tabular}{|c|}
$\begin{array}{c}\text { Single late seizure } \\
n=38\end{array}$ \\
\end{tabular} & $\begin{array}{c}\begin{array}{c}\text { Recurrent late seizures } \\
n=85\end{array} \\
\end{array}$ \\
\hline Age in years - median (IQR) ${ }^{\mathrm{a}}$ & $39(30-53)$ & $42(30-54)$ \\
\hline $\begin{array}{l}\text { Status epilepticus in the acute } \\
\text { phase }\end{array}$ & $6 / 36(17 \%)$ & $20 / 84(24 \%)$ \\
\hline $\begin{array}{l}\text { Acute symptomatic seizure } \\
\text { (excluding status epilepticus) }\end{array}$ & $19 / 36(53 \%)$ & $43 / 84(51 \%)$ \\
\hline Focal neurologic deficits & $26 / 37(70 \%)$ & $66 / 83(80 \%)$ \\
\hline Intracerebral hemorrhage & $22 / 37(60 \%)$ & $50 / 85(59 \%)$ \\
\hline Cerebral edema/infarct only & $11 / 37(30 \%)$ & $35 / 85(41 \%)$ \\
\hline $\begin{array}{l}\text { Sulcal subarachnoid } \\
\text { hemorrhage }\end{array}$ & $4 / 37(11 \%)$ & $14 / 85(17 \%)$ \\
\hline Subdural hematoma & $5 / 37(14 \%)$ & $3 / 84(4 \%)$ \\
\hline $\begin{array}{l}\text { Superior sagittal sinus } \\
\text { thrombosis }\end{array}$ & $21 / 37(57 \%)$ & $53 / 85(62 \%)$ \\
\hline $\begin{array}{l}\text { Decompressive } \\
\text { hemicraniectomy }\end{array}$ & $4 / 37(11 \%)$ & $13 / 85(15 \%)$ \\
\hline
\end{tabular}

Abbreviations: $I Q R=$ interquartile range

${ }^{a}$ No missing data 


\section{Neurology}

Late seizures in cerebral venous thrombosis

Mayte Sánchez van Kammen, Erik Lindgren, Suzanne M. Silvis, et al.

Neurology published online August 5, 2020

DOI 10.1212/WNL.0000000000010576

This information is current as of August 5, 2020

$\begin{array}{ll}\text { Updated Information \& } & \text { including high resolution figures, can be found at: } \\ \text { Services } & \text { http://n.neurology.org/content/early/2020/08/05/WNL.0000000000010 } \\ & \text { Th6.full } \\ \text { This article, along with others on similar topics, appears in the } & \text { following collection(s): } \\ & \text { All Epilepsy/Seizures } \\ & \text { http://n.neurology.org/cgi/collection/all_epilepsy_seizures } \\ & \text { Cerebral venous thrombosis } \\ & \text { http://n.neurology.org/cgi/collection/cerebral_venous_thrombosis } \\ & \text { Cohort studies } \\ & \text { http://n.neurology.org/cgi/collection/cohort_studies } \\ & \text { Prognosis } \\ & \text { http://n.neurology.org/cgi/collection/prognosis } \\ & \text { Stroke in young adults } \\ & \text { http://n.neurology.org/cgi/collection/stroke_in_young_adults } \\ & \text { Information about reproducing this article in parts (figures,tables) or in } \\ & \text { its entirety can be found online at: } \\ & \text { http://www.neurology.org/about/about_the_journal\#permissions } \\ & \text { Information about ordering reprints can be found online: } \\ \text { Permissions \& Licensing } & \text { http://n.neurology.org/subscribers/advertise }\end{array}$

Updated Information \& Services

Subspecialty Collections

Neurology $®$ is the official journal of the American Academy of Neurology. Published continuously since 1951, it is now a weekly with 48 issues per year. Copyright @ 2020 American Academy of Neurology. All rights reserved. Print ISSN: 0028-3878. Online ISSN: 1526-632X.

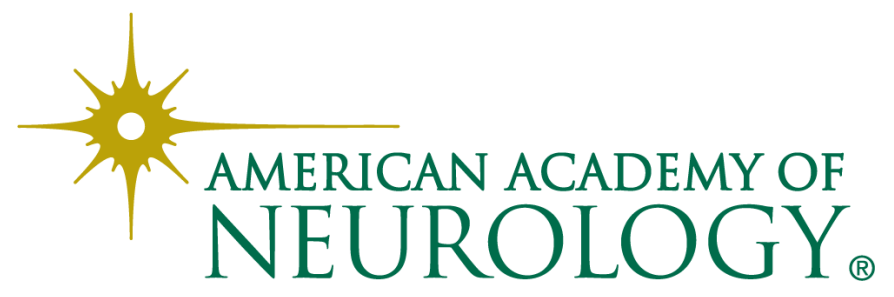

